\title{
Combination of Curcuma (Curcuma xanthorriza Roxb) and Awar-awar (Ficus septica Burm.F.) Ethanolic Extracts Enhance Doxorubicin to Modulate Cell Cycle Progression of T47D Cells
}

\author{
Laili Nailul Muna $a^{1,2}$ and Riris Istighfari Jenie ${ }^{1,2^{*}}$ \\ ${ }^{1}$ Faculty of Pharmacy, Gadjah Mada University, Indonesia \\ ${ }^{2}$ Cancer Chemoprevention Research Center, Faculty of Pharmacy, Gadjah Mada University, Indonesia
}

\begin{abstract}
One of the efforts to cure breast cancer is a combination of the chemotherapeutic agent with medicinal plants. This study was conducted to examine the activity of the combination between doxorubicin, curcuma rhizome (Curcuma xanthorriza Roxb.) ethanolic extract (CEE), and awar-awar leaves (Ficus septica Burm.f.) ethanolic extract (AAE) in inducing apoptosis and modulating the cell cycle progression in breast cancer T47D cells. The combination activity was performed using three series of concentration, I/3; I/6 and I/I 2 of IC 50 , The combination index (Cl) of doxorubicin, CEE and AEE was determined under MTT assay. The result showed that the combination of $10 \mu \mathrm{M}, 5 \mu \mathrm{g} / \mathrm{mL}$, I $\mu \mathrm{g} / \mathrm{mL}$ concentrations of doxorubicin, CEE and AEE respectively result in synergistic effect with $\mathrm{Cl}$ values less than I. The treatment exhibited the cell accumulation in S phase $(27.7 \%)$ against T47D breast cancer cells confirmed through cell cycle examination by flow cytometry. These results provided the evidence that CEE and the AEE can be developed as co-chemotherapeutic agents combined with doxorubicin to improve the effectiveness of breast cancer treatment.
\end{abstract}

Keywords : Curcuma xanthorriza Roxb., Ficus septica Burm.f., doxorubicin, cell cycle.

\section{INTRODUCTION}

A chemotherapeutic agent, like doxorubicin, is used for the breast cancer treatment frequently. However, the main problems that arise in the use of doxorubicin chemotherapeutic agents in the treatment of breast cancer are the emergence of side effects and resistance. The side effects of doxorubicin resulted in suppression of the immune system (Wattanapitayaku, et al., 2004) and resistance (Mechetner, et al., 1998). The use of coagents in combination with chemotherapeutic agents is an attempt to improve the effectiveness of cancer therapy agents while lowering the side effects of chemotherapy agent (Sharma, et al., 2004). Curcuma rhizome (Curcuma Roxb xanthorriza) and Awar-awar leaves (Ficus septica Burm.f.) are two of medicinal plants in Indonesia that used regularly for herbal therapy in breast cancer. Curcuma contains curcumin which is known to have anticancer activity with the mechanism of action of the antiproliferation and antiangiogenesis. In addition, curcumin is able to inhibit the activation of NF- $\mathrm{kB}$ (Foo and Nolan, 1999). Meanwhile, Awar-awar contains phenanthroindolizidine, an alkaloid that were known to have cytotoxic activity on cells HCT8, NUGC, Hone-1 (Damu, et al., 2005). Previous study showed that ethanolic extract of awar-awar leaves (EFS) exhibits cytotoxic activity suspected to induce apoptosis through suppression of protein expression antiapoptosis in MCF-7 cells (Sekti, et al., 2010). Moreover, Haryanti et al. also reported that AEE incombination with Sappan woods ethanolic extract increase the potensi of doxorubicin to induce apoptosis in MCF-7 cells (Haryanti, et al., 2016).

Based on the study above, ethanolic extract of awar-awar (AEE) and ethanolic extract of curcuma (CEE) are potential to be developed as an cochemotherapy agent in breast cancer treatment.

Submitted: Feb 18, 2018

Revised: Feb 25, 2018

Accepted: Feb 25, 2018

*Corresponding author e-mail: ririsjenie@gmail.com 
The combination of ethanolic extract of awar-awar and ethanolic extract of curcuma with doxorubicin are expected to reduce the dose and side effects of doxorubicin and breast cancer cell resistance due to the use of doxorubicin. This study is conducted to determine the synergistic effect of cytotoxic effect brought about by a combination of doxorubicin, ethanolic extract of curcuma (CEE) and ethanolic extract of awar-awar (AEE) through the induction of apoptosis and cell cycle modulation of T47D breast cancer cells.

\section{MATERIAL AND METHOD}

\section{Compounds and cell culture}

The samples were resulted from extraction using ethanol $70 \%$ where the dried powder of Curcuma and Awar-awar leaves were obtained from Balai Besar Pusat Penelitian Tanaman Obat dan Obat Tradisional (B2P2TOOT), Tawangmangu, Indonesia. While T47D cells were gifted from Prof. Masashi Kawaichi, Laboratorium of Gene Function in Animal, Graduate School of Biological Science, Nara Institute of Science and Technology (NAIST), Japan, and were grown in Dulbecco's Modified Eagle Media (DMEM) high glucose (Gibco), supplemented with $10 \%$ Fetal Bovine Serum (FBS Qualified, Gibco, Invitrogen USA), $1.5 \%(\mathrm{w} / \mathrm{w})$ penisilin-streptomisin (Gibco, Invitrogen USA), and $0.5 \%$ fungizone (Gibco, Invitrogen USA). Cells were incubated at $37^{\circ} \mathrm{C}$ and $5 \% \mathrm{CO}_{2}$.

\section{MTT assay}

T47D cells/well were grown in 96-well plate $\left(1 \times 10^{4} /\right.$ well $)$ before being exposured to samples treatment. For cell viability assay, cells were treated for 24 hours with increasing concentration of single treatment of CEE and AEE and in combination with doxorubicin. As negative control, only growth medium was added. At $100 \mu \mathrm{g} / \mathrm{mL}$ of MTT solution $(0.5 \mathrm{mg} / \mathrm{ml}$ in PBS $)$ was added to each well continued with incubation for 3 hours at $37^{\circ} \mathrm{C}$. The reaction was stopped by dilution with $10 \%(\mathrm{w} / \mathrm{v})$ Sodium Dodecyl Sulphate 10\% in $0.01 \mathrm{~N} \mathrm{HCl}$, and cells were incubated overnight. The absorbance was determined by using ELISA reader at $\lambda 595 \mathrm{~nm}$.

\section{Flowcytometry}

FACS analysis was carried out to investigate apoptosis quantification and cell cycle distribution. T47D cells $\left(5 \times 10^{5} /\right.$ well $)$ were grown in 6 -well plate and treated with CEE, AEE, doxorubicin (WAKO) and combination of them. Trypsinized adherent cells were collected and were prepared for detection. Cell apoptosis was detected by using a FITC-Annexin V Apoptosis Detection Kit (Biovision, USA). For cell cycle analysis, the trypsinized adherent cells were collected and detected by adding flow cytometry reagents $[(25 \mu \mathrm{L}$ propidium iodide (minimum $95 \%$ (HPLC), Sigma-Aldrich Co., St. Louis, MO, 63178, USA), $2.5 \mu \mathrm{L}$ RNase, $0.5 \mu$ l Triton-X (triton X-100 for GC, E.Merck, 64271, Darmstadt, Germany) in $500 \mu \mathrm{L}$ PBS)], followed by incubation at room temperature for 10 minutes. The cell suspension was transferred into a flow cytometer tube and its cell cycle profile was read by using flow cytometer FACS-Calibur. The cell cycle profile was analyzed by Flowing software.

\section{RESULTS}

\section{Cytotoxic combination effects of Doxorubicin, AEE and CEE in T47D Cell}

$\mathrm{IC}_{50}$ values obtained from the AEE and CEE respectively are $6.7 \pm 0.65 \mu \mathrm{g} / \mathrm{mL}$ and $29.3 \pm 1.76$ $\mu \mathrm{g} / \mathrm{mL}$. The $\mathrm{IC}_{50}$ value of the treatments showed that the AEE and CEE as a potent cytotoxic agent because the value earned is less than $100 \mu \mathrm{g} / \mathrm{mL}$ (Ueda, et al., 2002). Meanwhile, doxorubicin has $\mathrm{IC}_{50}$ value of $60 \mu \mathrm{M}$. Cytotoxic test of combination treatment was carried out at a concentration of $1 / 12$, $1 / 3$, and $1 / 6 \mathrm{IC}_{50}$ of each samples.

The combination of doxorubicin-CEE-AEE showed morphological changes and decrease in density of the cells after the combination happened (Fig. 1). The combination of the $1 / 6 \mathrm{IC}_{50} \mathrm{CEE}$ concentration $(5 \mu \mathrm{g} / \mathrm{mL})$, AEE $(1 \mu \mathrm{g} / \mathrm{mL})$, and 10 $\mu \mathrm{M}$ doxorubicin can lower the viability of T47D cells of $55.77 \%$ (Fig. 2b) with CI values of 0.63 (CI $<1)$ (Table 1) shows a synergistic effect among the three test compounds. These results indicate ethanolic extract of curcuma and awar-awar can be used as an agent to be combined with doxorubicin in T47D cells. 


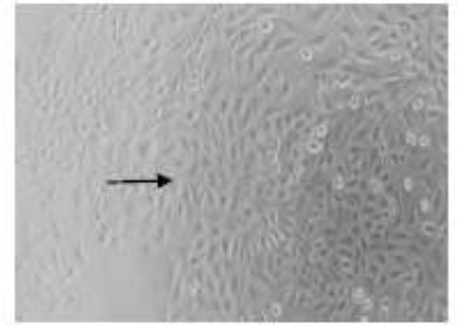

A.

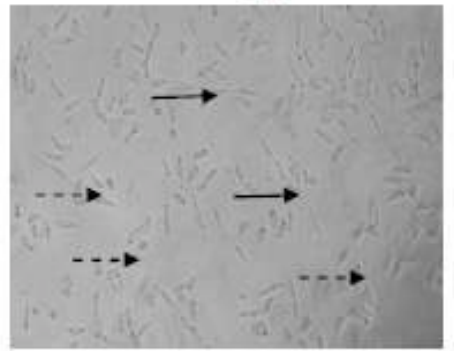

C.

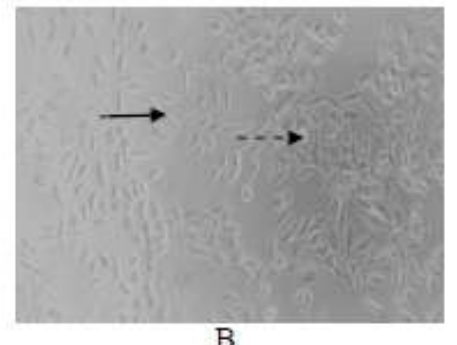

B.

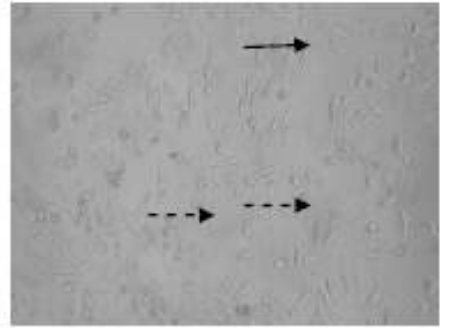

D.

Figure I. The effect of combination treatment of AEE-CEE-doxorubicin against T47D cell growth. About 8,000 cells / wells in 96-well plates were incubated for 24 hours in Hi-glucose DMEM media without or with treatment. Observations were made under inverted microscope (a) Cells control; (B) Combination of AEE-CEE-Doxorubicin I/I2 IC50; (C) The combination of doxorubicin AEE-CEE- IC50 I/6; (D) A combination of doxorubicin I/3 CEE- AEEIC 50 . Morphology of living T47D cell is shown by the image $(\longrightarrow)$ and cells undergoing morphological changes is indicated by the arrow breaking $(--\rightarrow)$. Cl values combination of AEE-CEE-Doxorubicin show a synergistic effect $(\mathrm{Cl}<\mathrm{I})$.

Table I. Combination Index $(\mathrm{CI})$ Value of doxorubicin combination with the AEE, and CEE on T47D cells

\begin{tabular}{ccc}
\hline Rasio Konsentrasi & $\begin{array}{c}\text { \% Viabilitas AEE-CEE- } \\
\text { Doxorubicin }\end{array}$ & $\mathrm{Cl}$ \\
\hline I/I $\quad$ IC & & \\
I/6 $I C_{50}$ & 60.67 & 0,74 \\
I/3 IC 50 & 44.23 & 0,63 \\
\hline
\end{tabular}

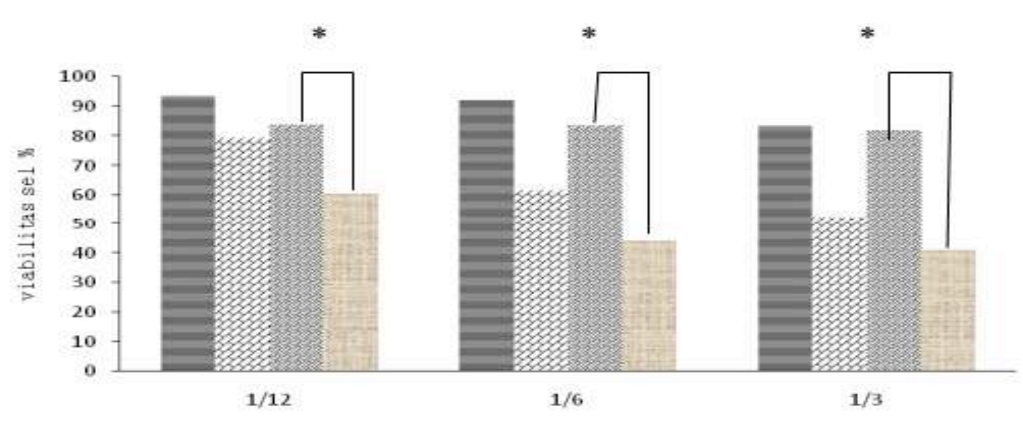

\begin{tabular}{lccccccccccccc}
\hline $\operatorname{EET}(\mu \mathrm{g} / \mathrm{ml})$ & 2,5 & + & - & + & 5 & + & - & + & 10 & + & - & + \\
\hline $\operatorname{EEA}(\mu \mathrm{g} / \mathrm{ml})$ & 0,5 & - & + & - & + & 1 & - & + & + & + & 2 & + & + \\
\hline $\operatorname{Dox}(\mathrm{nM})$ & 5 & - & + & + & 10 & - & + & + & + & - & + & + & + \\
\hline
\end{tabular}

Figure 2. Combination relationship graph of AEE-CEE and doxorubicin against T47D cell viability. Combination of the AEE-CEE-Doxorubicin. About 8,000 cells / wells were given a combination treatment and were incubated for 24 hours. Observed changed in viability T47D cell and combination index analysis. Combination treatment shows viability loss of optimum Doxorubicin with synergistic effect. * Significant differences $(p<0.05)$. 


\section{Combination of AEE-CEE-doxorubicin modulate cell cycle progression in T47D breast cancer cells}

The result showed that the AEE causes an accumulation in S phase, while in the CEE the accumulation occurs in S phase and G2/M (Fig. 3). The combination of CEE, AEE with doxorubicin leads to accumulation of the cell cycle in the S phase by $31.24 \%$ compared to single doxorubicin treatment causes cells to accumulate in G2/M phase (Fig. 3). The percentage of cell accumulation combination due to the combination treatment in $\mathrm{S}$ phase is increased to $21.34 \%$ compared to $9.90 \%$ single doxorubicin. Cell accumulation is possible because of a cell cycle arrest in the phase.

\section{Combination of AEE-CEE-doxorubicin induce cell apoptosis}

The value of cell death in sequence on a single doxorubicin and its combination with ethanolic extract of curcuma and awar-awar is $5.79 \%$ and $9.5 \%$. The results shows that the ethanolic extract of curcuma and awar-awar affect the sensitivity of the T47D cells as a result of treatment of doxorubicin, but have not been able to induce apoptosis of T47D breast cancer cells significantly (Fig. 4).

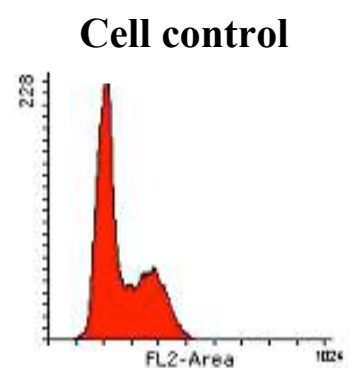

$1 / 6 \mathrm{IC}_{50}$ Doxorubicin

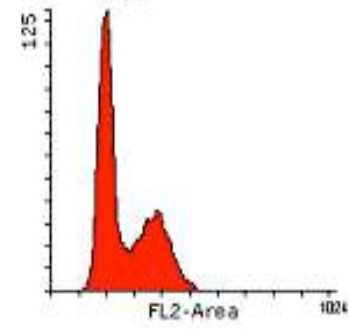

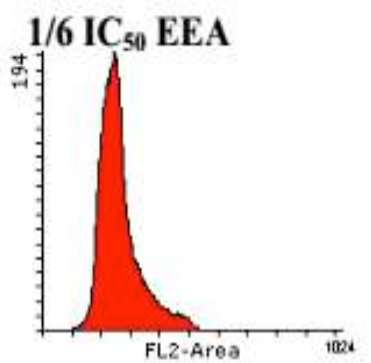

$1 / 6 \mathrm{IC}_{50}$ EET

$1 / 6 \mathrm{IC}_{50} \mathrm{EEA}, 1 / 6 \mathrm{IC}_{50} \mathrm{EET}, 1 / 6 \mathrm{IC}_{50}$

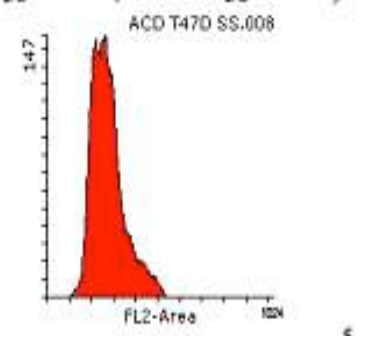

Figure 3. Detection of cell cycle distribution using flow cytometry. T47D cells $\left(5 \times 10^{5}\right)$ were grown in 6 well plates and were incubated for 24 hours in high glucose DMEM media without or with treatment. Flow cytometry detection using PI reagent against T47D cells after AEE treatment $\mathrm{I} \mu \mathrm{g} / \mathrm{ml}$, CEE $5 \mu \mathrm{g} / \mathrm{ml}$, Dox IOnM and a combination of all those three. Combination of AEE-CEE-Doxorubicin. Flow cytometry Analysis using flowing 

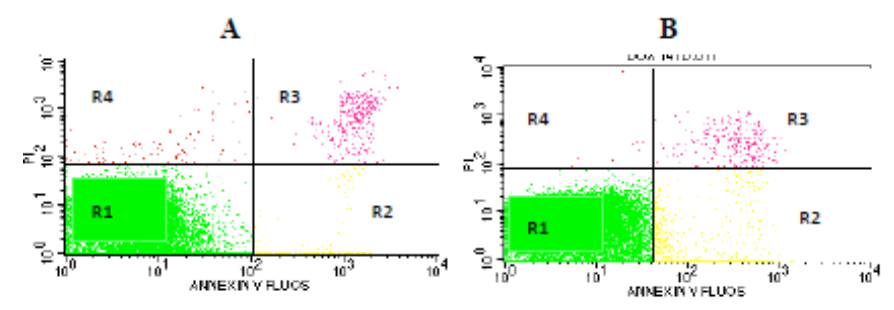

C

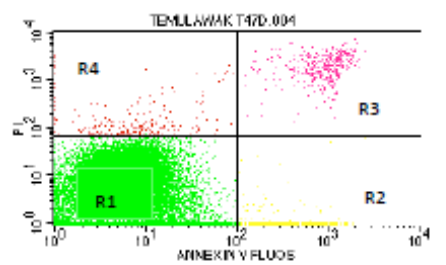

D

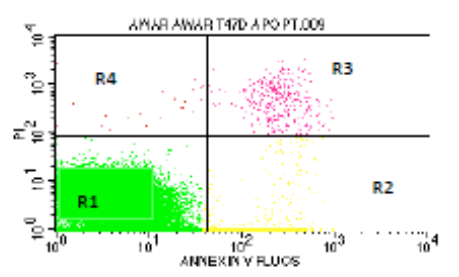

$\mathbf{E}$

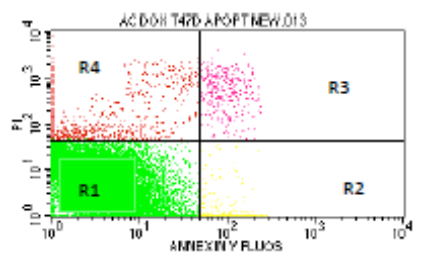

Figure 4. Effect of CEE, AEE, Doxorubicin treatment and AEE-CEE-doxorubicin against cell death. About $5 \times 105$ cells grown in 6-well plates and were incubated for 24 hours in high glucose DMEM media with or without treatment. Flowcytometry detection of cell death using V-FITC / PI annexin against T47D breast cancer cells after treatment using $5 \mu \mathrm{g} / \mathrm{ml} \mathrm{CEE}, \mathrm{I}$ ug / $\mathrm{ml} \mathrm{AEE}, 10 \mathrm{nM}$ doxorubicin, and a combination of all those three . RI quadrant shows a living cell, R2: early apoptosis, R3: late apoptosis, R4: necrosis. (a) Cells control; (B) Combination of AEECEE-Doxorubicin I/I2 IC50; (C) The combination of doxorubicin AEE-CEE- IC 50 I/6; (D) A combination of doxorubicin I/3 CEE- AEE-IC50.

\section{DISCUSSION}

Single treatment analysis of AEE in breast cancer T47D cells causes an accumulation of cells in $\mathrm{S}$ phase $(23.38 \%)$. It is caused due to the upregulation of CDK inhibitor p21 (Nugroh, et al., 2013). The CEE treatment causes the cells to accumulate in $\mathrm{G} 2 / \mathrm{M}$ phase $(22.10 \%)$ and the $\mathrm{S}$ phase $(15.03 \%)$. This is consistent with previous studies that curcumin against Colo 205 cells also cause $\mathrm{G} 2 / \mathrm{M}$ arrest, and this is due to the down-regulation of Cdc24c, Cdk1, and Cyclin B (Su, et al., 2006). The xanthorizol contained in CEE against colon cancer cells HCT 116 also can lead to S arrest and G2/M arrest (Kang, et al., 2009). In addition, the analysis of the cell cycle at doxorubicin single treatment against T47D breast cancer cells causes an accumulation of cells in G2/M phase (24.30\%). This corresponds to previous research regarding cell cycle analysis. Single treatment of doxorubicin chemotherapeutic agent causes the cells to accumulate in $\mathrm{G} 2 / \mathrm{M}$ phase in T47D cells. The accumulation of cells in $\mathrm{G} 2 / \mathrm{M}$ phase as a result of treatment of doxorubicin causes DNA damage thus affecting the ATM-ATR signaling. This will activate the protein kinase Chk1 and Chk2, inhibiting $\mathrm{Cdc} 2 / \mathrm{Cyclin} \mathrm{B}$, causing $\mathrm{G} 2 / \mathrm{M}$ arrest (Kolb, et al., 2012).

The combination treatment of the AEE-CEEDoxorubicin can change cell accumulation of G2/M phase to the $\mathrm{S}$ phase of doxorubicin treatment. So the inhibition process occurs during the synthesis process of genetic material. In the $\mathrm{S}$ phase, cyclin $\mathrm{A}$ binds to Cdk2 that activate cells to the G2 phase. This activation is inhibited by $27, \mathrm{p} 21$, and $\mathrm{p} 57$ (Shah and Schwartz, 2001). So the combination treatment of CEE, AEE, and doxorubicin could potentially cause up-regulation of p21 that can inhibit cyclin a complex binds to Cdk2. Moreover, the possibility can also be caused due to the downregulation of cyclin $\mathrm{A}$, which plays a role in $\mathrm{S}$ phase, causing $\mathrm{S}$ phase arrest.

Study focusing on the molecular pathways involved by Nugroho, 2013 showed that the 
ethanolic hexane insoluble fraction (HIF) of awarawar leaves were able to induce apoptosis through p53 pathway emphasis on independent, i.e. through the suppression of Bcl-2 expression. In addition, the combination of HIF and doxorubicin could induce apoptosis by increasing the expression of cleavagePARP cutting through PARP (Nugroho, et al., 2013). Curcumin was able to suppress levels of NF-kappaB due to the activation of TNF-alpha, which was one of apoptosis signaling pathways, so that the effect of curcumin on inhibiting NF- $\mathrm{KB}$ could stimulate apoptosis and suppresses proliferation (Aggarwal, et al., 2006). However, the combination of CEE, AEE, and doxorubicin has not been able to lead to the induction of apoptosis of the breast cancer T47D cells. This is possibly due to the reaction between compounds in the extract content that has not been able to increase apoptosis induction. The mechanism of cytotoxic compounds contained in the AEE and CEE is possible through p53-dependent pathway.

Curcuma genus has been reported to inhibit proliferation of T47D breast cancer cells (Widowati, et al., 2011). Current results improve the existing scientific evidence about the activities of ethanolic extract of curcuma and awar-awar against T47D breast cancer cells in combination with doxorubicin. However, the study also required further research to determine the proteins involved in knowing the molecular mechanisms that mediate synergism in combination of ethanolic extract of awar-awar and curcuma, such as protein expression of $\mathrm{p} 53, \mathrm{Bcl}-2$ and NF- $\mathrm{KB}$ by in vitro on breast cancer T47D cells.

\section{CONCLUSION}

The conclusion of this research is that awarawar extract and curcuma extract has potential to increase the sensitivity of doxorubicin against T47D breast cancer cells by in vitro. The combination of AEE, CEE and doxorubicin has a synergistic effect in giving cytotoxic effects on breast cancer cells by mechanisms of cell cycle modulation. of NF-kB by in vitro on breast cancer cells T47D.

\section{REFERENCES}

Aggarwal, B.B. Shishodia, S. Sandur, S.K. Pandey, M.K. and Sethi, G., 2006, Inflammation and cancer: how hot is the link?, Biochem. Pharmacol., 72(II), 1605-I62I.

Damu, A.G., Kuo, P.C., Shi, L.S., Li, C.Y., Kuoh, C.S., $\mathrm{Wu}, \quad$ P.L., et al., 2005, Phenanthroindolizidine alkaloids from the stems of Ficus septica, J. Nat. Prod., 68(7), 107I-1075.

Foo, S.Y. and Nolan, G.P., 1999, NF-kappaB to the Rescue: RELs, Apoptosis and Cellular Transformation, Trends Genet., 15(6), 229235.

Haryanti, S., Pramono, S., Murwanti, R. and Meiyanto, E., 2016, The Synergistic Effect of Doxorubicin and Ethanolic Extracts of Caesalpinia sappan L. Wood and Ficus septica Burm. f. Leaves on Viability, Cell Cycle Progression, and Apoptosis Induction of MCF7 Cells, Indones. J. Biotechnol., 2I(I), 29-37

Kang, J., Park, K., Chung, W., Hwang, J. and Lee, S., 2009, Xanthorrhizol, a natural sesquiterpenoid, induces apoptosis and growth arrest in HCTII6 human colon cancer cells, J. Pharmacol. Sc.i, I I I(3), 27684.

Kolb, R.H., Greer, P.M., Cao, P.T., Cowan, K.H. and Yan, Y., 2012, ERKI/2 signaling plays an important role in topoisomerase II poisoninduced G2/M checkpoint activation, PloS one, 7(I I), e5028I.

Mechetner, E., Kyshtoobayeva, A., Zonis, S., Kim, H., Stroup, R. and Garcia, R., 1998, Levels of Multidrug Resistance (MDRI) PGlycoprotein Expression by Human Breast Cancer Correlate with in vitro Resistance to Taxol and Doxorubicin, Clin. Cancer Res., 4(2), 389-398.

Nugroho, A.E., Hermawan, A., Putri, D.D., Novika, A. Meiyanto, E. and Kawaichi, M., 2013, Combinational effects of hexane insoluble fraction of Ficus septica Burm. F. and doxorubicin chemotherapy on T47D breast cancer cells, Asian Pac. J. Trop. Biomed., 3(4), 297-302.

Sekti, D.A., Mubarok, M.F., Armandani, I., Junedy, S. and Meiyanto, E., 2010, Ekstrak Etanolik Daun Awar-awar (Ficus septica Burm. f.) Memacu Apoptosis Sel Kanker Payudara MCF-7 Melalui Penekanan Ekspresi Bcl-2, Maj. Obat Tradis., 15(3), 100-104. 
Shah, M.A. and Schwartz, G.K., 200I, Cell CycleMediated Drug Resistance: An Emerging Concept in Cancer Therapy, Clin. Cancer Res., 7(8), 2168-2181.

Sharma, G., Tyagi, A., Singh, R., Chan, D. and Agarwal, R., 2004, Synergistic Anti-cancer Effects of Grape Seed Extract and Conventional Cytotoxic Agent Doxorubicin against Human Breast Carcinoma Cells, Breast Cancer Res. Treat., 85(I), I- 12.

Su, C.C., Geng Lin, J. and Wei Chen, G., 2006, Down-regulation of $\mathrm{Cdc} 25 \mathrm{c}, \mathrm{CDKI}$ and Cyclin $\mathrm{BI}$ and Up-regulation of Weel by Curcumin Promotes Human Colon Cancer Colo 205 Cell Entry into G2/M phase of Cell Cycle, Cancer Genom. Proteom., 3(I), 55-61.

Ueda, J.Y., Tezuka, Y., Banskota, A.H., Le Tran, Q., Tran, Q.K., Harimaya, Y., et al., 2002,
Antiproliferative activity of Vietnamese medicinal plants, Biol. Pharm. Bull., 25(6), 753-760

Wattanapitayaku, S.K., Chularojmontri, L., Herunsalee, A., Charuchongkolwongse, S., Niumsakul, S. and Bauer, J.A., 2004, Screening of Antioxidants from Medicinal Plants for Cardioprotective Effect against Doxorubicin Toxicity, Basic Clin. Pharmacol. Toxicol., 96(I), 80-87.

Widowati, W., Mozef, T., Risdian, C., Ratnawati, H., Tjahjani, S. and Sandra, F., 20II, The Comparison of Antioxidative and Proliferation Inhibitor Properties of Piper betle L., Catharanthus roseus [L] G.Don, Dendrophtoe petandra L., Curcuma mangga Val. Extracts on T47D Cancer Cell Line, Int. Res. J. Biochem. Bioinform., I (2), 22-28. 